\title{
КОРЕЛЯЦИЙНИЙ АНАЛІЗ ПОКАЗНИКІВ ГЕМОСТАЗУ I ФУНКЦІОНАЛЬНОГО СТАНУ ПЕЧІНКИ ЗА ГОСТРОГО КАЛЬКУЛЬОЗНОГО ХОЛЕЦИСТИТУ
}

Вступ. Гострий калькульозний холецистит (ГКХ) характеризується розвитком певних симптомів від місцевого запального процесу до значних функціональних порушень у печінці. Активність системи гемостазу прямо пов'язана з функціональним станом печінки, оскільки гепатоцити є основним місцем синтезу більшості протеїнів, зокрема протеїнів системи згортання крові.

Мета дослідження - встановити взаємозв'язки між показниками системи гемостазу і фрункціонального стану печінки у хворих на ГКХ, неускладнений та ускладнений обтураційною жовтяницею (ОЖ), 3 використанням кореляційного аналізу.

Методи дослідження. Об'єктом дослідження були плазма та сироватка крові 47 хворих на неускладнений ГКХ та 32 хворих на ГКХ з ОЖ. Для порівняння було досліджено плазму та сироватку крові 25 практично здорових осіб, які становили контрольну групу. Визначали показники системи гемостазу (кількість тромбоцитів, протромбіновий час, активований парціальний тромбопластиновий час, концентрацію загального фрібриногену, вміст розчинних фрібрин-мономерних комплексів, активність антитромбіну III та Хагеман-залежного фрібринолізу), а також показники функціонального стану печінки (каталітичну активність лужної фросфратази, активність гамма-глутамілтрансфрерази і холінестерази та концентрацію

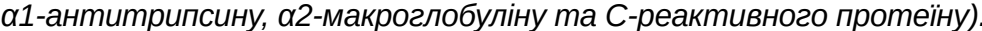

Результати й обговорення. Виявлені кореляційні зв'язки дозволяють визначити ступінь спряженості процесів. Чим менша кількість зв'язків виявляється і слабша спряженість процесів, тим гнучкішою стає система, яка реагує на патологічну зміну внутрішнього середовища. Найбільшу кількість кореляційних зв'язків встановлено в контрольній групі пацієнтів. У хворих на ГКХ без ускладнень спостерігали тенденцію до зниження кількості зв'язків, де а1-антитрипсин найбільше корелював з досліджуваними показниками. Зменшення кількості та зміну структури кореляційних зв'язків було виявлено у хворих на ГКХ з ОЖ. Також встановлено появу нових кореляційних зв'язків між досліджуваними показниками в даній групі пацієнтів.

Висновок. Встановлені вірогідні кореляційні зв'язки при неускладненому ГКХ та ускладненому ОЖ свідчать про напруженість адаптаційних механізмів системи гемостазу і функціонального стану печінки при ускладненні запального процесу.

КЛЮЧОВІ СЛОВА: кореляційний аналіз; гострий калькульозний холецистит; обтураційна жовтяниця; гепатоцити; система гемостазу.

ВСТУП. Гострий калькульозний холецистит (ГКХ) та його ускладнення за своїм соціальним значенням займають провідне місце серед захворювань гепатобіліарної системи у зв'язку з їх стрімким поширенням і високою смертністю [1, 2]. Він характеризується розвитком певних симптомів - від місцевого запального процесу до значних фрункціональних порушень у печінці. Негативна дія токсичних речовин на печінку спричинює широкий спектр патологічних змін на різних рівнях ії̈ організації [3].

(с Ю. М. Степась, Л. Є. Лаповець, В. М. Акімова, Г. Б. Лебедь, 2017.
Активність системи гемостазу прямо пов'язана з фрункціональним станом печінки, оскільки гепатоцити є основним місцем синтезу більшості протеїнів, зокрема протеїнів системи згортання крові $[3,4]$.

Тому метою дослідження було встановити взаємозв'язки між показниками системи гемостазу і функціонального стану печінки у хворих на ГКХ, неускладнений та ускладнений обтураційною жовтяницею (ОЖ), з використанням кореляційного аналізу. 
МЕТОДИ ДОСЛІДЖЕННЯ. ПіД нашим спостереженням перебувало 47 хворих на неускладнений ГКХ, 32 хворих на ГКХ з ОЖ та 30 практично здорових осіб, які становили контрольну групу. Діагноз ГКХ було встановлено на підставі клінічних, лабораторно-біохімічних та інструментальних методів.

Показники системи гемостазу, а саме протромбіновий час (ПЧ), активований парціальний тромбопластиновий час (АПТЧ), вміст розчинних фібрин-мономерних комплексів (РФМК), визначали в плазмі крові за допомогою реактивів фірми “ТЕХНОЛОГІЯ-СТАНДАРТ" (Росія, м. Барнаул). Для визначення активності Хагеман-залежного фібринолізу (ХЗФ) та антитромбіну III (АТIII) використовували набори реактивів фірми "SIMKO LTD" (м. Львів). Концентрацію фрібриногену в плазмі крові визначали за методикою Р. А. Рутберг $[4,5]$.

Рівні показників ферментативної активності печінки (лужної фоссратази (ЛФ), холінестерази (XЕ) та гамма-глутамілтрансферази (ГГТ)) визначали колориметричним методом на автоматичному біохімічному аналізаторі COBAS INTEGRA 400 PLUS ("ROCHE DIAGNOSTICS GmbH", Німеччина) [2, 3].

Для визначення концентрації С-реактивного

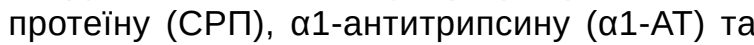

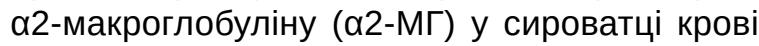
використовували імунотурбідиметричний метод і автоматичний біохімічний аналізатор COBAS INTEGRA 400 PLUS ("ROCHE DIAGNOSTICS GmbH", Німеччина) [6-8].

Взяття крові для досліджень проводили відразу при госпіталізації хворих у відділення шляхом забору з ліктьової вени за допомогою системи Vacutainer.
Статистичну обробку отриманих даних проведено методами варіаційної статистики 3 використанням пакета прикладних програм STATISTIKA 6.0.

Результати досліджень аналізували методом параметричної кореляції з визначенням лінійного коефіцієнта кореляції Пірсона (r). При значенні $r \leq 0,25$ кореляційний зв'язок вважали слабким, якщо ж 0,25<r<0,75 - помірним. При значенні $\mathrm{r} \geq 0,75$ такий взаємозв'язок розцінювали як сильний. Додатне значення коесріцієнта свідчить про пряму залежність між величинами (прямий, позитивний зв'язок), коли збільшення значення однієї ознаки збільшує значення іншої. Від'ємне значення коефріцієнта вказує на обернений (зворотний, негативний) зв'язок між досліджуваними показниками, коли зростання однієї ознаки призводить до зменшення іншої. Значимість коефіцієнта кореляції оцінювали за допомогою t-критерію Стьюдента при вірогідності похибки р<0,05 [9].

3 метою графічної візуалізації значень коефріцієнта кореляції будували кореляційні плеяди.

РЕЗУЛЬТАТИ Й ОБГОВОРЕННЯ. ПрОВівШИ кореляційний аналіз отриманих даних у досліджуваних групах пацієнтів, ми встановили низку взаємозв'язків між отриманими значеннями (рис. 1). Виявлені кореляційні зв'язки дозволяють визначити ступінь спряженості процесів. Чим менша кількість зв'язків виявляється і слабша спряженість процесів, тим гнучкішою стає система, яка реагує на патологічну зміну внутрішнього середовища.

Найбільшу кількість кореляційних зв'язків було встановлено в контрольній групі пацієнтів (рис. 1, А). Вірогідні прямі зв'язки середньої сили виявлено між АTIII, а2-МГ і вмістом тромбоци-

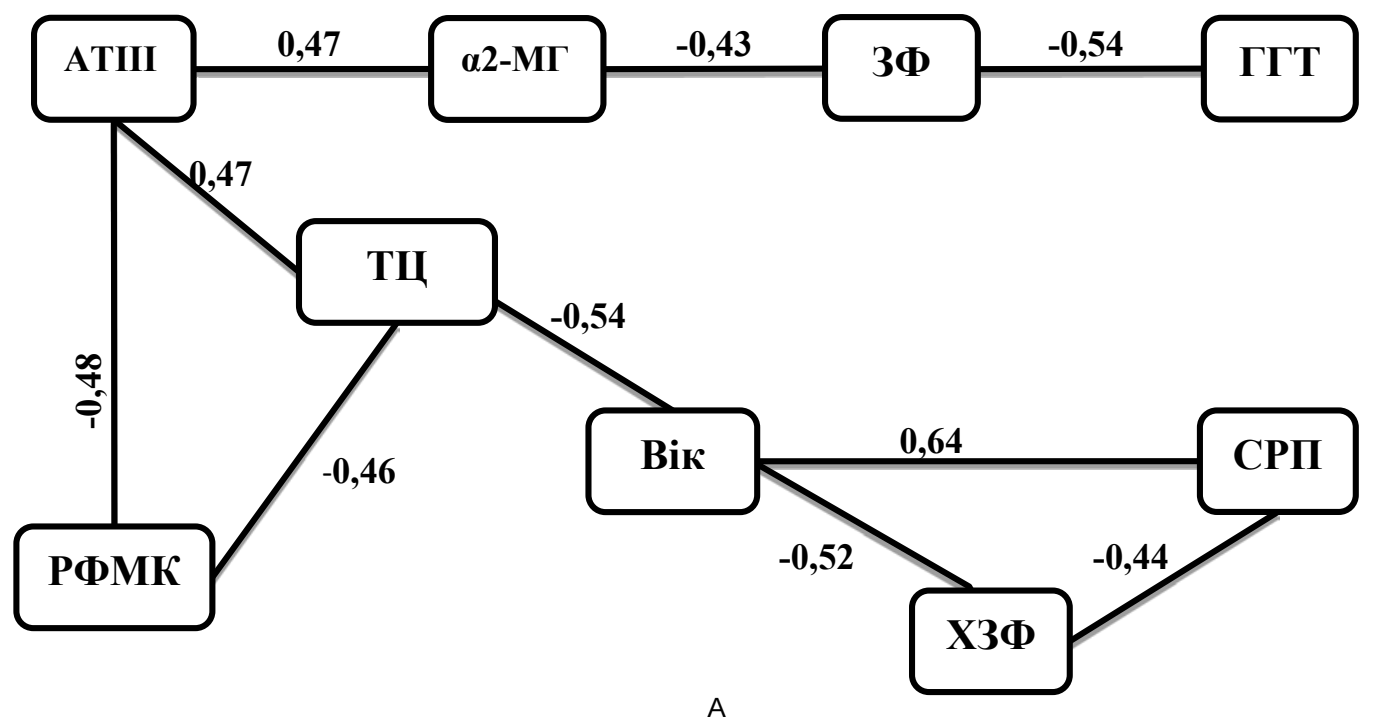

Рис. 1. Кореляційні плеяди взаємозв'язків: А - контрольної групи $(p<0,05)$. 


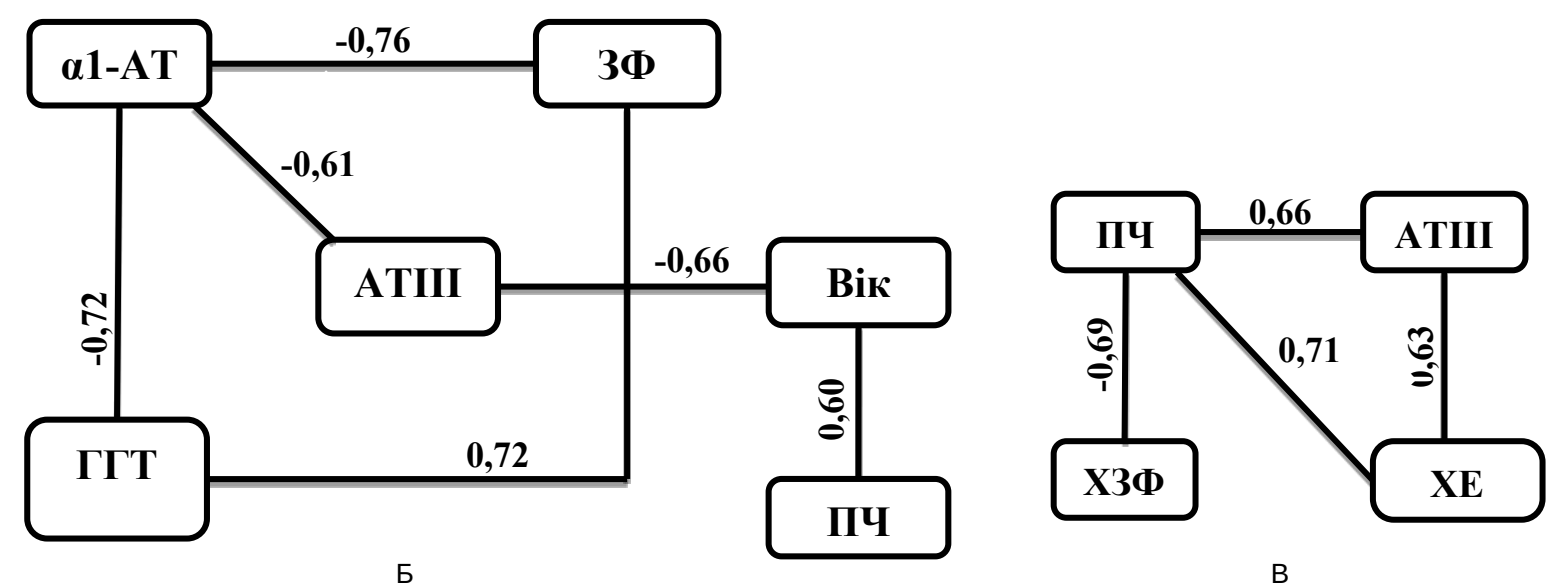

Рис. 1. Кореляційні плеяди взаємозв'язків (продовження): Б - хворих на неускладнений ГКХ $(p<0,05)$; В - хворих на ГКХ $з$ ОЖ $(\mathrm{p}<0,05)$.

тів (ТЦ) $(r=0,47, p<0,05)$, між СРП та віком пацієнтів $(r=0,64, p<0,05)$. Вірогідні обернені зв'язки середньої щільності встановлено між $\alpha 2-\mathrm{MГ} \mathrm{та}$ загальним фрібриногеном (3Ф) $(r=-0,43, p<0,05)$, між ЗФ і ГГТ $(r=-0,54, p<0,05)$, між АТІІІ та РФМК $(r=-0,48, p<0,05)$, між ХЗФ і СРП $(r=-0,44, p<0,05)$.

У хворих на ГКХ без ускладнень спостерігали тенденцію до зменшення кількості зв'язків. Найбільшу кількість зв'язків встановлено для a1-АТ, який вірогідно корелював зворотним сильним зв'язком із ЗФ (r=-0,76, $p<0,05)$, зворотним зв'язком середньої сили - 3 ATIII ( $r=-0,61$, $\mathrm{p}<0,05)$ та ГГТ $(r=-0,72, p<0,05)$. Крім того, було виявлено вірогідний прямий зв'язок середньої щільності між ЗФ і ГГТ $(r=0,72, p<0,05)$.

Зменшення кількості та зміну структури кореляційних зв'язків було виявлено у хворих на ГКХ з ОЖ. Встановлено появу нових кореляційних зв'язків. Так, ПЧ вірогідно корелював прямим зв'язком середньої сили з АTIII $(r=0,66, p<0,05)$ та XE $(r=0,71, p<0,05)$ і зворотним зв'язком середньої сили - $Х$ ХФ $(r=-0,69, p<0,05)$. Також було виявлено вірогідний прямий кореляційний зв'язок середньої сили з XE $(r=0,63, p<0,05)$ та вірогідний обернений зв'язок середньої сили між АПТЧ і СРП $(r=-0,66, p<0,05)$.

ВИСНОВКИ. 1. Порівняно з виявленими вірогідними кореляційними зв'язками в практично здорових осіб при неускладненому ГКХ спостерігали тенденцію до зменшення кількості зв'язків. Ядром кореляційних зв'язків був вміст a1-AT.

2. У хворих на ГКХ з ОЖ було встановлено зменшення кількості вірогідних кореляційних зв'язків зі зміною їх структури, а також появу нових кореляційних зв'язків, що свідчить про напруженість адаптаційних механізмів системи гемостазу і фрункціонального стану печінки при ускладненні запального процесу.

\section{СПИСОК ЛІТЕРАТУРИ}

1. Десятерик В. І. Профрілактика печінкової недостатності у хворих на обтураційну жовтяницю / В. І. Десятерик, Д. В. Мамчур // Клініч. хірургія. -2014. - № 3. C. $65-67$.

2. Шевчук М. Г. Постдекомпресійні диссуункції печінки у хворих на обтураційні жовтяниці / М. Г. Шевчук, О. Л. Ткачук, І. М. Шевчук. - Івано-Франківськ : Вид-во Івано-Франків. мед. ун-ту, 2006. - 212 с.

3. Гонський Я. І. Біохімія людини : підручник / Я. І. Гонський, Т. П. Максимчук, М.І.Калинський. Тернопіль : Укрмедкнига, 2002. - 744 с.
4. Паталах І. І. Система гемостазу та білки гострої фрази запалення при тромбогенних патологія / /. І. Паталах, С. О. Кудінов // Укр. біохім. журн. - 2008. № 1 (80). - C. 5-12.

5. New fundamentals in hemostasis/H. H. Varsteeg, J. W. M. Heemskerk, M. Levi [et al.] // Physiol. Rev. 2013. - 93. - Р. 327-358.

6. Зорин Н. А. Роль белков семейства макроглобулинов в регуляции воспалительных реакций / Н. А. Зорин, В. Н. Зорин, Р. М. Зорина // Биомед. химия. - 2006. - № 3 (52). - С. 229-238. 
7. Teckman J. H. Alpha-1 antitrypsin and liver disease: mechanisms of injury and novel interventions / J. H. Teckman, N. Mangalat // Expert Rev. Gastroenterol. Hepatol. - 2015. - 9 (2). - P. 261-268.
8. Garcia-Ferrer I. $\alpha 2-$ Macroglobulins: Structure and function / I. Garcia-Ferrer, A. Marrero, F. X. Gomis-Ruth // Subcell Biochem. - 2017. - Vol. 83. - P. 149-183.

9. Боровиков В. STATISTICA: искусство анализа данных на компьютере. Для профессионалов / В. Боровиков. - СПб. : Питер, 2001. - 656 с.

\section{REFERENCES}

1. Desiateryk, V.I., \& Mamchur, D.V. (2009). Profilaktyka pechinkovoi nedostatnosti u khvorykh na obturatsiinu zhovtianytsiu [Prevention of liver instability and patients with obstructive jaundice]. Klinichna khirurhiia - Clinical Surgery, 3, 65-67 [in Ukrainian].

2. Shevchuk, M.H., Tkachuk, O.L., \& Shevchuk, I.M. (2006). Postdekompresiini dysfunktsii pechinky u khvorykh na obturatsiini zhovtianytsi [Postdecompression liver dysfunction in patients with obstructive jaundice]. Ivano-Frankivsk: Vyd-vo Ivano-Frank. med. un-tu [in Ukrainian].

3. Honskyi, la.I., Maksymchuk, T.P., \& Kalynskyi, M.I. (2002). Biokhimiia liudyny [Human biochemistry]. Ternopil: Ukrmedknyha [in Ukrainian].

4. Patalakh, I.I., \& Kudinov, S.O. (2008). Systema hemostazu ta bilky hostroi fazy zapalennia pry trombohennykh patolohiiakh [System of hemostasis and proteins of the acute phase of inflammation at thrombogenic pathologies]. Ukrainskyi biokhimichnyi zhurnal - Ukrainian Biochemical Journal, 1 (80), 5-12 [in Ukrainian].
5. Varsteeg, H.H., Heemskerk, J.W.M., \& Levi, M. (2013). New fundamentals in hemostasis. Physiol. Rev., 93, 327-358.

6. Zorin, N.A., Zorin, V.N., \& Zorina, R.M. (2006). Rol belkov semeistva makroglobulinov $v$ reguliatsii vospalitelnykh reaktsyy [The role of proteins of the family of macroglobulins in the regulation of inflammatory reactions]. Biomeditsinskaya khimiya-Biomedical Chemistry, 3 (52), 229-238 [in Russian].

7. Teckman, J.H., \& Mangalat, N. (2015). Alpha-1 antitrypsin and liver disease: mechanisms of injury and novel interventions. Expert Rev. Gastroenterol. Hepatol., 9 (2), 261-268. doi: 10.1586/17474124.2014.943187.

8. Garcia-Ferrer, I., Marrero, A., \& Gomis-Ruth, F.X.

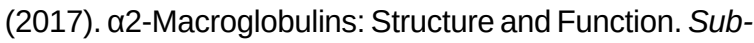
cell Biochem., 83, 149-183. doi: 10.1007/978-3-31946503-6 6.

9. Borovikov, V. (2001). STATISTICA: iskusstvo analiza dannyh na kompyutere. Dlya professionalov [STATISTICA: the art of data analysis on a computer. For professionals]. Saint-Petersburg: Piter [in Russian].

Ю. М. Степась, Л. Е. Лаповец, В. М. Акимова, Г. Б. Лебедь ЛЬВОВСКИЙ НАЦИОНАЛЬНЫЙ МЕДИЦИНСКИЙ УНИВЕРСИТЕТ ИМЕНИ ДАНИЛА ГАЛИЦКОГО

\section{КОРРЕЛЯЦИОННЫЙ АНАЛИЗ ПОКАЗАТЕЛЕЙ ГЕМОСТАЗА И ФУНКЦИОНАЛЬНОГО СОСТОЯНИЯ ПЕЧЕНИ ПРИ ОСТРОМ КАЛЬКУЛЕЗНОМ ХОЛЕЦИСТИТЕ}

\section{Резюме}

Вступление. Острый калькулезный холецистит (ГКХ) характеризуется развитием определенных симптомов - от местного воспалительного процесса до значительных фрункциональных нарушений в печени. Активность системы гемостаза напрямую связана с фрункциональным состоянием печени, поскольку гепатоциты являются основным местом синтеза больиинства протеинов, в частности протеинов системы свертывания крови.

Цель исследования - установить взаимосвязь между показателями системы гемостаза и фрункционального состояния печени у больных острым калькулезным холециститом (ГКХ), неосложненным и осложненным обтурационной желтухой (ОЖ), с использованием корреляционного анализа.

Методы исследования. Объектом исследования были плазма и сыворотка крови 47 больных неосложненным ГКХ и 32 больных ГКХ с ОЖ. Для сравнения были исследованы плазма и сыворотка крови 25 рактически здоровых лиц, составивших контрольную группу. Определяли показатели системы гемостаза (количество тромбоцитов, протромбиновое время, активированное парциальное тромбопластиновое время, концентрацию общего фрибриногена, содержание растворимых фрибрин-мономерных комплексов, активность антитромбина III и Хагеман-зависимого фрибринолиза), а также показатели фрунк- 
ционального состояния печени (каталитическую активность щелочной фросфатазы, активность гамма-глутамилтрансфреразы, холинэстеразы и концентрацию а1-антитрипсина, а2-макроглобулина и С-реактивного протеина.

Результаты и обсуждение. Выявленные корреляционные связи позволяют определить степень сопряженности процессов. Чем меньше количество связей проявляется и слабее сопряженность процессов, тем более гибкой становится система, которая реагирует на патологическую смену внутренней среды. Наибольшее количество корреляционных связей установлено в контрольной группе пациентов. У больных ОКХ без осложнений наблюдали тенденцию к снижению количества связей, где $\alpha 1$-антитрипсин больше всего коррелировал с исследуемыми показателями. Уменьшение количества и изменение структуры корреляционных связей были обнаружены у больных ОКХ с ОЖ. Также установлено появление новых корреляционных связей между исследуемыми показателями в данной группе пациентов.

Вывод. Установленные достоверные корреляционные связи при неосложненном ГКХ и осложненном ОЖ свидетельствуют о напряженности адаптационных механизмов системы гемостаза и функционального состояния печени при осложнении воспалительного процесса.

КЛЮЧЕВЫЕ СЛОВА: корреляционный анализ; острый калькулезный холецистит; обтурационная желтуха; гепатоциты; система гемостаза.

J. M. Stepas, L. E. Lapovets, V. M. Akimova, H. B. Lebed DANYLO HALYTSKYI LVIV NATIONAL MEDICAL UNIVERSITY

\section{CORRELATION ANALYSIS OF HEMOSTASIS INDICATORS AND FUNCTIONAL LIVER CONDITIONS FOR ACUTE CALCULOSIS CHOLECYSTITIS}

\section{Summary}

Introduction. Acute calculous cholecystitis (ACC) is characterized by the development of certain symptoms - from the local inflammatory process to significant functional disorders in the liver. The activity of the hemostasis system is directly related to the functional state of the liver, since hepatocytes are the main site for the synthesis of most proteins, in particular the proteins of the blood coagulation system.

The aim of the study - to establish the relationship between the hemostasis system and the functional state of hepatocytes in patients with acute calculous cholecystitis (ACC), uncomplicated and complicated by obstructive jaundice $(O J)$ using a correlation analysis.

Research Methods. The subject of the study was plasma and serum of 47 patients with uncomplicated ACC (group I) and 32 patients with ACC with OJ (group II). For comparison, serum and blood plasma of 25 virtually healthy individuals, who were in the control group, were examined. The parameters of the hemostasis system platelet count (prothrombin time (PT), activated partial thromboplastin time (APTT), total fibrinogen concentration (TFC), soluble fibrin-monomer complexes (SFMC), antithrombin III (ATIII) and Hageman-dependent fibrinolysis activity were determined (HDF). The determination of indicators of the liver function of the catalytic activity of alkaline phosphatase $(A L P)$, gamma-glutamyltransferase (GGT) and cholinesterase (CHE) and the concentration of $\alpha 1$-antitrypsin ( $\alpha 1-A T)$, $\alpha 2-$ macroglobulin ( $\alpha 2-M G)$ and C-reactive protein (CRP) was also made.

Results and Discussion. The revealed correlations allow determining the degree of conjugacy of processes. The less the number of bonds is the weaker conjugacy of processes, the more flexible becomes the system that responds to the pathological change of the internal environment. The greatest number of correlation bonds was established in the control group of patients. In patients with ACC without complications, there was a tendency to decrease the number of bonds, where $\alpha 1-A T$ correlated most with the investigated parameters. The reduction of the amount and the change of the structure of correlation bonds were found in patients with ACC with OJ. A new correlation between the studied parameters in this group of patients has also been established.

Conclusion. The established correlation bonds in uncomplicated ACC and complicated OJ indicate the tension of the adaptive mechanisms of the hemostasis system and the functional state of the liver when the inflammatory process complicates.

KEY WORDS: correlation analysis; acute calculous cholecystitis; obstructive jaundice; hepatocytes; hemostasis system.

Адреса для листування: Ю. М. Степась, Львівський національний медичний університет імені Данила Галицького, вул. Пекарська, 69, Львів, 79010, Україна, e-mail: stepas1983@i.ua. 